\title{
Enhancing Biocontrol Agents by Hydroquinone and Salicylic Acid for Controlling Root-Rot and Wilt Diseases of Lupine
}

\section{Zian, A.H. ${ }^{1}$; El-Gendy, H.M.R. ${ }^{1}$ and Shehata, H.S. ${ }^{2}$}

1- Plant Pathology Research Institute, Agricultural Research Center, Giza, Egypt.

2- Soils, Water and Environment Research Institute, Agricultural Research Center, Giza, Egypt.

Tilization of Trichoderma harzianum and Bacillus subtilis as biocontrol agents and chemical inducers hydroquinone (HQ) and salicylic acid (SA) as plant systemic inducers resistance individually or in combinations was studied for controlling root rot and wilt diseases and growth promoting of lupine plants in vitro and in vivo. Both antagonistic bioagents and chemical inducers either individually or in combination inhibited linear growth of Fusarium oxysporum f.sp. lupini and Rhizoctonia solani with variable degrees compared to the check. Bacillus subtilis + HQ and B. subtilis + SA recorded the highest reduction of mycelial growth in both pathogenic fungi. Under the greenhouse and field conditions, all treatments significantly reduced damping-off and root rot/wilt incidence and increased the survived plants. The combination of biocontrol agents and chemical resistance inducers were more effective than using each of them individually. Also, under field conditions, these treatments significantly increased plant growth parameters and yield components in both locations (Ismailia and Sers El-layian Res. Stations Farms during 2017/2018 growing season). In physiological studies, photosynthetic pigments, activities of defense-related enzymes, including peroxidase (PO), polyphenoloxidase (PPO) and total phenols content (TPC) were increased in plants treated with biocontrol agents combined with chemical inducers compared to using each of them individually. Generally, the combination of biocontrol agents and chemical resistance inducers recorded the best results for controlling damping-off, root rot/wilt diseases, plant growth parameters and yield components in the greenhouse and field. Such these treatments may be used as a part of integrated disease management for field crops in order to avoid the use of fungicides.

Keywords: lupine, Rhizoctonia, Fusarium, Bacillus subtilis, Trichoderma harzianum, Salicylic acid, Hydroquinone.

White lupine (Lupinus albus L.) belongs to the leguminous family which has been cultivated in Egypt for human and animal nutrition, also for medical and industrial purposes. It can be considered as a friendly crop to the environment related to its efficient nitrogen fixation system, in addition to its improvement to the 
traditional cereal rotation and protein supply in low input farming systems (Julier et al., 1994). Soil-borne fungal diseases are among the most important factors limiting the yield production of lupine, resulting in serious economic losses. Several soilborne pathogens including Fusarium oxysporum, Rhizoctonia solani, F. solani and Macrophomina phaseolina attack the roots and stem base of lupine plants (Zian, 2011). Biological control is the best alternative especially against soil borne pathogens (Jayalakshmi et al., 2009). Among the various isolates of Trichoderma spp, i.e. T. asperellum, T. harzianum, T. virens, T. viride, and T. hamatum are used against various diseases of crop plants especially with soil borne pathogens. Bacillus spp. and Trichoderma spp. Have been used as biocontrol agents and also as plant growth promoting (Bacon and White, 2000). In addition, T. harzianum induces plant systemic resistance against soil borne pathogens, while $B$. subtilis produces secondary metabolites which suppress the pathogens (Asaka and Shoda, 1996). Recently, B. subtilis and T. harzianum have been extensively used as biocontrol agents and promotes plants against pathogens (Asaka and Shoda, 1996; Okoth et al., 2011).

Induced resistance using abiotic inducers is also a promising approach to control diseases caused by soil borne pathogens. It has been reported that salicylic acid induced systemic resistance in chickpea against wilt under controlled environments (Saikia et al., 2003; Sarwar et al., 2010 and Sarhan, 2018). Also, hydroquinone has been reported to decrease the incidence of lupine root rot and wilt diseases caused by $F$. solani and $F$. oxysporum and the treatments were accompanied with a significant increase in lupine growth parameters, yield components and physiological aspects. (Ali et al., 2009). While, El-Wakil (2003) mentioned that presowing treatment of peanut seeds with antioxidant hydroquinone significantly decreased the incidence of seed-borne fungi, viz. Aspergillus flavus, A. niger, Penicillium spp., F. solani, F. oxysporum, R. solani, Sclerotium bataticola, Trichothicium sp., Cladosporium sp., Cephalosporium sp. and Bipolaris sp. and enhanced the plant growth parameters.

Biological control of soil borne pathogens is often attributed to improved nutrition that boosts host defences or to direct inhibition of pathogen growth and activity. Amendment with certain abiotic factors (inducers) appears to stimulate the disease resistance by indirectly stimulating indigenous populations of microorganism that are beneficial to plant growth and antagonistic to pathogens. For example chitin amendment of soil has been found to stimulate the growth of chitinolytic microorganisms (De Boer et al., 1999 and Sarhan et al., 2018), increase the biocontrol activity and stimulate the expression of plant defense proteins (Roby et al., 1987). All these effects may culminate in enhancing plant protection. Similarly, salicylic acid and hydroquinone amendments were tested in combination with biocontrol agents (B. subtilis and/or T. harzianum). Saikia et al. (2003) tested the efficiency of Pseudomonas fluorescence with or without SA amendment in

Egypt. J. Phytopathol., Vol. 47, No. 1 (2019) 
chickpea against Fusarium wilt infection. The application of $P$. fluorescence with SA recorded the highest protection of chickpea seedlings against wilting.

Both biotic and abiotic inducers are known to have eliciting activities leading to a variety of defense reactions in host plants in response to microbial infection, including the accumulation of pathogenesis related PR-proteins (Nafie and Mazen, 2008), defence related enzymes (Govindappa et al., 2010), accumulation of phenolic compounds (Nafie and Mazen, 2008).

The objectives of the present study are aimed to evaluate chemical inducers and/or biocontrol agents treatments individually or in combination for inducing resistance against lupine root-rot and wilt diseases and growth promotion under greenhouse and field conditions. It also evaluated the efficiency of these treatments for inducing peroxidase and polyphenoloxidase activities and for producing total phenols contents associated with secondary plant metabolites to express resistance to pathogen infection.

\section{Materials and Methods}

\section{1- The used materials:}

\section{1 -Plant material}

Lupine seeds (Lupinus albus L.), cultivar Giza-2 were obtained from the Legume Res. Dept., Field Crops Res. Inst., ARC, Giza, Egypt.

\section{2-Biocontrol agents:}

Trichoderma harzianum and B. subtilis as biocontrol agents were kindly provided by Legume and Forage Dis. Res. Dept., Plant Pathol. Res. Inst., ARC, Giza, Egypt.

\section{3 -Chemical inducers:}

Salicylic acid (SA) and hydroquinone (HQ) as a plant systemic resistance inducers were obtained from El-Nasr Co. for Intermediate Chemicals, Egypt (NCIC).

\section{4 - Fungal Pathogens and preparation of inocula:}

The fungi, i.e. R. solani and F. oxysporum f.sp. lupini were kindly provided by Legume and Forage Dis. Res. Depart., Plant Pathol. Res. Ins., ARC., Giza, Egypt.

Inocula of $R$. solani and $F$. oxysporum f.sp. lupini were prepared by growing the fungi in $500 \mathrm{cc}$ glass bottles containing 100 gram sterilized sorghum grains medium. Each bottle was inoculated with actively growing disc $(0.5 \mathrm{~cm})$ taken from four days old $R$. solani or seven days old $F$. oxysporum cultures. Bottles were incubated at 25 $\pm 1^{\circ} \mathrm{C}$ for 15 days to encourage more rapid and uniform colonization of the sorghum grains. 


\section{2-Laboratory experiment:}

2.1 -Effect of antagonistic biocontrol agents and chemical inducers on R. solani and F. oxysporum f.sp. lupini linear growth:

A-Biocontrol agents:

Trichoderma harzianum and the tested pathogenic fungi ( $R$. solani and $F$. oxysporum f.sp. lupini) were cultured on PDA medium for four days in case of $R$. solani or seven days in case of $F$. oxysporum cultures at $25 \pm 1^{\circ} \mathrm{C}$ then a disc $(0.5 \mathrm{~cm})$ of the antagonistic fungal colony was cut and placed opposite to the colony of the pathogenic fungal isolates on PDA medium. On the other hand, B. subtilis isolate was streaked at opposite ends of PDA plates near the edge and incubated at $25 \pm 1{ }^{\circ} \mathrm{C}$ for $24 \mathrm{hr}$, and then a mycelial disc $(0.5 \mathrm{~cm})$ of the tested fungus was placed in the centre of each plate. Colony diameter was measured and the percentage of growth inhibition for the pathogen was calculated.

\section{$B$ - Chemical inducers:}

The effect of chemical inducers on the growth of the pathogenic isolates was evaluated on PDA medium. Twenty $\mathrm{mL}$ of PDA medium containing 5mM SA or $10 \mathrm{mM} H Q$ was poured in the plate and inoculated with the pathogenic fungi. Colony diameter was measured and the percentage of growth inhibition for the pathogen was calculated.

\section{C- Combination between biocontrol agents and chemical inducers:}

Flasks $(500 \mathrm{ml})$ containing $200 \mathrm{~mL}$ PDA medium were amended with $5 \mathrm{mM} \mathrm{SA}$ and $10 \mathrm{mM} \mathrm{HQ}$ individually, then each flask was poured in 10 plates. The plates were inoculated with the desired antagonistic isolate and pathogenic isolates as mentioned before. For control treatment, the agar plug of only the pathogenic isolate was placed on PDA plate. The inoculated plates were incubated at $25 \pm 1^{\circ} \mathrm{C}$ until the colony of control colonized the plate. At this point, colony diameter was measured and the percentage of growth inhibition for the pathogen was calculated.

\section{2 - Biochemical activities of biocontrol agents:}

-Preparation of biocontrol agents' culture filtrate:

Trichoderma harzianum was grown in Potato Dextrose Broth (PDB) at $28^{\circ} \mathrm{C}$ on the shaker at $140 \mathrm{rpm}$ in the dark for 10 days. The fungal culture was filtrated through filter paper, then centrifuged and sterilized using membrane filter of pore size $(0.22 \mathrm{Mm})$. The resulted filtrate was kept under cooling in the refrigerator in a dark bottle till use. While, single colony of B. subtilis ( $48 \mathrm{~h}$ old) was inoculated in nutrient broth medium $\left(0.1 \%\right.$ petrol mixed as carbon source), kept at $37^{\circ} \mathrm{C}$ for $48 \mathrm{~h}$. At $12,000 \mathrm{rpm}$ for $12 \mathrm{~min}$ at $4^{\circ} \mathrm{C}$ the cultural broth of $\mathrm{B}$. subtilis was centrifuged. The culture filtrate was collected and filtered through a Millipore filter of $0.45 \mu \mathrm{m}$ to remove bacterial cell.

Egypt. J. Phytopathol., Vol. 47, No. 1 (2019) 


\section{-Extraction method of toxins:}

The culture filtrates were adjusted to $\mathrm{pH} 5.1$ and extracted three times with 250 $\mathrm{ml}$ ethyl acetate/1 Litter. The aqueous layer was removed and the solvent layer was washed three times with $35 \mathrm{ml}$ of $5 \%$ aqueous sodium bicarbonate solution. The solvent layer was concentrated under vacuum till dryness and re-dissolved in ethyl acetate (Sawai et al., 1981).

\subsection{1 -Determination of T. harzianum gliotoxin:}

Toxins were determined by thin layer chromatography (TLC). Crude samples were spotted $2 \mathrm{~cm}$ from the bottom on a pre-coated sheet of silica gel $60 \mathrm{~F}_{254}$ (Merck). The plates were subjected to different solvent systems. the compositions of the solvent systems were expressed in volume ratio as follows: chloroform: methanol : acetic acid : (90:9:1), chloroform : methanol : acetic acid (90:6:4) (Tarber et al., 1977), chloroform : methanol : acetic acid (90:6:2) (Sawai et al., 1981), benzene : methanol : acetic acid (18:1:1) (Ahmed, 2000) and petroleum ether : chloroform : acetic acid (50:49:1).

Toxins spots were located by their fluorescence on the chromatograms under short and long wave UV light (254 and $366 \mathrm{~nm}$ ) against standard curves and were also analyzed by using UV spectrophotometer.

\subsection{2 - Determination of B. subtilis $\beta$-1,3 glucanase (Laminarinase) activity:}

$B$. subtillis $\beta-1,3$ glucanase (Laminarinase) activity was determined using the method described by Somogyi (1945), absorbance at $600 \mathrm{~nm}$. One unit of enzyme was defined as the amount of enzyme, which liberates $1 \mu \mathrm{mol}$ of reducing sugar equivalent to glucose per one min under the standard assay conditions.

\subsection{3- Determination of B. subtillis $\beta$-1,4 glucanase (cellulase) activity:}

The method adopted by Miller (1959) was used. The resulted samples were then cooled to room temperature and measured the absorbance at $540 \mathrm{~nm}$. One unit of cellulase activity was defined as the amount of enzyme that could hydrolyze Carboxymethyl cellulose and release $1 \mu \mathrm{mol}$ of glucose within 1 min reaction time at $50{ }^{\circ} \mathrm{C}$

\subsection{4- Determination of chitinase activity:}

Chitinase activity was determined using the method described by Monreal and Reese (1969). One unit of enzyme activity was defined as the amount of enzyme that produced $1 \mu \mathrm{mol}$ of $\mathrm{N}$-acetylglucosamine per min.

\section{3-Greenhouse experiments:}

The effects of biocontrol agents (T. harzianum and B. subtilis) and chemical inducers (SA and HQ) as seed soaking individually or in combination against lupine root-rot and wilt diseases incited by $R$. solani, $F$. oxysporum f. sp. lupini were evaluated under greenhouse located at Ismailia Agric. Res. Station, Agric. Res. Centre. Pots $(30 \mathrm{~cm}$ in diameter) with a bottom drainage hole were sterilized by 
dipping in 5\% formalin solution for 15 minutes, and left for one week until complete formalin evaporation. Pots were filled with disinfested sandy clay soil 1:2 (V/V). Soil infestation was achieved by mixing the inoculum of $R$. solani or $F$. oxysporum f. sp. lupini with the soil at the rate of $2 \%$ of soil weight (Papavizas and Davey, 1962). Sterilized un-inoculated grounded sorghum grains were added to the disinfested soil at the same rate to serve as healthy control. The infested soil was mixed thoroughly and watered every 2 days for a week before planting to stimulate the fungal growth and ensure its distribution in the soil. Five seeds of treated lupine seeds were sown in each pot and pots were irrigated directly. Five replicated pots were used for each particular treatment. All pots were irrigated when necessary, and watered once a week to near field capacity with a $0.1 \%$ 15:15:15 (N:P:K) fertilizer solution in the first month and kept in a greenhouse under natural conditions. Trichoderma harzianum grown on potato dextrose liquid medium at $25 \pm 1^{\circ} \mathrm{C}$ for 7 days were adjusted to $2 \times 10^{6} \mathrm{cfu} / \mathrm{mL}$. Cell suspension of $B$. subtilis grown on nutrient broth medium for 3 days at $28 \pm 1{ }^{\circ} \mathrm{C}$ was adjusted to $2.5 \times 10^{7} \mathrm{cfu} / \mathrm{mL}$. SA and $\mathrm{HQ}$ were prepared as solutions at 5 and $10 \mathrm{mM}$. respectively. Lupine seeds were disinfected by applying the Topsin-M 70® $70 \%$ WP (Thiophanate-methyl), at the recommended dose $(1 \mathrm{~g} / \mathrm{L})$ for $1 \mathrm{hr}$. The combination of biocontrol agents and chemical inducers were prepared by dissolving chemical inducers in suspension of the biocontrol agents. Lupine seeds were soaked for $1 \mathrm{hr}$ in the following treatments: 1, SA $(5 \mathrm{mM}) ; 2$, HQ. $(10 \mathrm{mM}) ; 3$, T. harzianum $\left(2 \times 10^{6} \mathrm{cfu} / \mathrm{mL}\right) ; 4$, B. subtilis $\left(2.5 \times 10^{7} \mathrm{cfu} / \mathrm{mL}\right) ; 5, \mathrm{SA}+$ T. harzianum $; 6, \mathrm{SA}+$ B. subtilis $; 7, \mathrm{HQ}+T$. harzianum ; 8, HQ + B. subtilis ; 9, Topsin M-70® ; 10, control and 11, healthy control.

\section{4 - Disease assessment:}

Disease incidence (DI\%) was determined by recording pre-emergence dampingoff, post-emergence damping off, root-rotted plants, wilted plants and the percentage of survived plants after 15,30, and 90 days of sowing, respectively according to the following formula:

$$
\begin{aligned}
& \text { Pre-emergence }(\%)=\frac{\text { Total No. of un-germinated seeds }}{\text { Total No. of planted seeds }} \times 100 \\
& \text { Post-emergence }(\%)=\frac{\text { Total No. of rotted seedlings }}{\text { Total No. of planted seeds }} \times 100
\end{aligned}
$$

$\begin{array}{ll}\text { Survived seedlings }= & \begin{array}{l}\text { Total No. of planted seeds }-(\text { pre }+ \text { post emergence }+ \text { root } \\ \text { rotted and } / \text { or wilted plants })\end{array}\end{array}$

Reduction or increasing (\%) over the infected control was also calculated according to the following formula:

$$
\text { Reduction or increasing }(\%)=\frac{\text { DI of control - DI of treatment }}{\text { DI of control }} \times 100
$$


Percentages of early and late wilt were recorded after 30 and 90 days of sowing, respectively, while the number of the survived plants was recorded 120 days after sowing.

\section{5-Field experiments:}

Field experiment was carried out at Ismailia and Sers El-layian Res. Stations Farms during 2017/2018 growing season to evaluate the efficiency of tested biocontrol agents (T. harzianum and B. subtilis) and chemical inducers (SA and HQ) individually or in combination for controlling root-rot and wilt diseases and their effect on growth and yield parameters under field conditions. The experimental design was a complete randomized block with three replicates. The experimental unit area was $9 \mathrm{~m}^{2}(3 \times 3 \mathrm{~m})$. Each unit comprised of 6 rows; each was $3 \mathrm{~m}$ in length and $50 \mathrm{~cm}$ width. Lupine seeds (cv. Giza-2) were soaked in the solutions/ suspensions of the treatments as described before for $1 \mathrm{hr}$. The treated seeds were sown in hills $25 \mathrm{~cm}$ apart on both sides of the 6 ridges in both locations, with one seed per hill. In control treatment, lupine seeds were soaked in water for $1 \mathrm{hr}$ and sown at the same rate. At harvest, plant height $(\mathrm{cm})$, number of branches/plant, number of pods/ plant, and weight of seeds/plant, 100-seed weight and total yield (kg/feddan) were measured.

5.1- Effect of lupine seed treatment with inducers on activity of oxidative enzymes and phenol content.

An experiment was carried out to determine activity of oxidative enzymes and phenol content. Lupine plants were grown as mentioned before in field experiment. Fifteen days after sowing, activity of peroxidase (PO), polyphenoloxidase (PPO) and phenol contents was determined in tissue extracts of lupine plants.

Extraction and assay of peroxidase (PO) activity were carried out according to Chakraborty and Chatterjee (2007).

Extraction and assay of polyphenoloxidase enzyme (PPO) were carried out according to Sadasivam and Manickam (1996).

Total phenol contents in plant leaves were estimated with the procedure given by Zilesin and Ben- Zaken (1993).

\section{2- Photosynthetic pigments determination}

The total chlorophyll amounts, chlorophyll a, chlorophyll $\mathrm{b}$ and carotenoids pigments were determined in the leaves of plants by the method of Arnon (1949).

\section{6- Statistical analysis}

The obtained data were subjected to computer statistical software (ASSISTAT) originated by Silva and Azevedo (2009). Data analyzed using analysis of variance (ANOVA), and mean values were compared using Duncan's multiple range test at a significance level of $\mathrm{P} \leq 0.05$. 


\section{Results}

\section{1- Laboratory experiments:}

\section{1- Effect of biocontrol agents and chemical inducers on linear growth of the} pathogenic fungi:

Data in Table (1) show that the tested biocontrol agents and chemical resistance inducers either individually or in combination significantly decreased linear growth of the two tested fungi with variable degrees. Generally, biocontrol agents were able to reduce linear growth of the tested pathogenic fungi more than chemical inducers. Also, the combinations of biocontrol agents and chemical inducers were more effective than using any of them individually. Whereas, B. subtilis + SA and $B$. subtilis + HQ were the most effective where they recorded the highest percentages of reduction in the linear growth of all the tested pathogenic fungi. However, SA followed by HQ individually recorded the lowest reduction of growth of all the tested fungi.

Table (1) Effect of some biocontrol agents and chemical inducers on the growth of the pathogenic fungi

\begin{tabular}{lcccc}
\hline \multirow{1}{*}{ Treatments } & \multicolumn{2}{c}{ R. solani } & \multicolumn{2}{c}{ F. oxysporum f.sp. lupini } \\
\cline { 2 - 5 } & $\begin{array}{c}\text { Linear } \\
\text { growth } \\
(\mathrm{mm})\end{array}$ & $\begin{array}{c}\text { Reduction } \\
\%\end{array}$ & $\begin{array}{c}\text { Linear } \\
\text { growth } \\
(\mathrm{mm})\end{array}$ & $\begin{array}{c}\text { Reduction } \\
\%\end{array}$ \\
\hline Trichoderma harzianum & $35.00 \mathrm{~d}$ & 61.11 & $31.00 \mathrm{c}$ & 65.60 \\
Bacillus subtilis & $30.00 \mathrm{e}$ & 66.66 & $26.00 \mathrm{~d}$ & 71.11 \\
Salicylic acid (SA) & $45.00 \mathrm{~b}$ & 50.00 & $38.00 \mathrm{~b}$ & 57.77 \\
Hydroquinone (HQ) & $41.00 \mathrm{c}$ & 54.44 & $33.00 \mathrm{c}$ & 63.33 \\
T. harzianum + SA & $30.00 \mathrm{e}$ & 66.66 & $25.00 \mathrm{~d}$ & 72.22 \\
T. harzianum + HQ & $28.00 \mathrm{ef}$ & 68.88 & $20.00 \mathrm{e}$ & 77.77 \\
B. subtilis + SA & $25.00 \mathrm{f}$ & 72.22 & $18.00 \mathrm{e}$ & 80.00 \\
B. subtilis +HQ & $18.00 \mathrm{~g}$ & 80.00 & $10.00 \mathrm{f}$ & 88.88 \\
Topsin M-70® & $00.00 \mathrm{~h}$ & 100.0 & $00.00 \mathrm{~g}$ & 100.0 \\
Control & $90.00 \mathrm{a}$ & - & $90.00 \mathrm{a}$ & - \\
\hline
\end{tabular}

Different letters indicate significant differences among treatments within the same column according to least significant difference test $(p \leq 0.05)$.

Egypt. J. Phytopathol., Vol. 47, No. 1 (2019) 


\section{2- Antibiosis activity of biocontrol agents:}

Biocontrol agents are known to produce various fungal cell wall-degrading lytic enzymes like $\beta-1-3$ glucanase, cellulase ( $\beta, 1-4$ glucanase) and chitinase which are involved in the antagonistic activity against the tested fungi. Data shown in Table (2) indicate that the activities of lytic enzymes were high

Table (2): Antibiosis activity of the antagonistic biocontrol agents.

\begin{tabular}{cccc}
\hline Biocontrol agents & \multicolumn{3}{c}{ Enzymes activity } \\
\hline & $\begin{array}{c}\beta-1,3 \text { glucanase } \\
\text { activity }(1 \mu / \mathrm{ml})\end{array}$ & $\begin{array}{c}\beta-1,4 \text { glucanase } \\
\text { activity }(1 \mu / \mathrm{ml})\end{array}$ & $\begin{array}{c}\text { Chitinase activity } \\
\text { Activity }(1 \mu \\
/ \mathrm{ml})\end{array}$ \\
Bacillus subtilis & 38.30 & 51.80 & 30.90 \\
\hline $\begin{array}{c}\text { Trichoderma } \\
\text { harzianum }\end{array}$ & Gliotoxin $(\mathrm{mg} / \mathrm{L})$ & Chitinase activity $(1 \mu / \mathrm{ml})$ \\
& 80.52 & 0.877 \\
\hline
\end{tabular}

2- Greenhouse experiment:

- Effect of biocontrol agents and chemical inducers on the incidence of lupine rootrot and Fusarium wilt diseases incidence:

Data presented in Tables (3, A and B) show that all treatments reduced dampingoff and root rot/wilt diseases incidence and increased survived plants of lupine plants which have been artificially infested with tested pathogens ( $R$. solani and/ or $F$. oxysporum f.sp. lupini) compared to untreated control treatment with variable degrees. Soaking seeds in biocontrol agents combined with chemical inducers reduced damping-off and root rot/wilt incidence more than used individually. On the other hand, in case of artificial infestation by $R$. solani. The combination between each of HQ and/or SA and T. harzianum and combined treatment (B. subtilis + HQ) recorded the highest protection against $R$. solani followed by B. subtilis + SA. While, seed soaked in B. subtilis or SA recorded the lowest ones. Also, in case of artificial infestation by $F$. oxysporum f.sp. lupini the combination between each of HQ and $T$. harzianum recorded the highest protection followed by each of $B$. subtilis + SA, B. subtilis + HQ and T. harzianum + SA. 
Table (3): Effect of some biocontrol agents and chemical inducers on root-rot and Fusarium wilt diseases incidence of lupine plants grown in artificially infested soil by Rhizoctonia solani (A) or Fusarium oxysporum f.sp. lupini (B) under greenhouse conditions.

(A) Rhizoctonia solani:

\begin{tabular}{|c|c|c|c|c|c|c|}
\hline \multirow{2}{*}{ Treatments } & \multicolumn{2}{|c|}{ Damping - off $\%$} & \multicolumn{2}{|c|}{ Root rot \% } & \multirow{2}{*}{$\begin{array}{c}\text { Survived } \\
\text { Plants } \\
\%\end{array}$} & \multirow{2}{*}{$\begin{array}{c}\text { Increasing } \\
\%\end{array}$} \\
\hline & Incidence $\%$ & Reduction $\%$ & Incidence $\%$ & Reduction $\%$ & & \\
\hline T. harzianum & $6.60 \mathrm{abc}$ & 50.74 & $10.0 \mathrm{ab}$ & 39.75 & $83.40 \mathrm{~cd}$ & 19.14 \\
\hline B. subtilis & $10.0 \mathrm{ab}$ & 25.37 & $10.0 \mathrm{ab}$ & 39.75 & $80.0 \mathrm{~d}$ & 14.28 \\
\hline Salicylic acid (SA) & $10.0 \mathrm{ab}$ & 25.37 & $10.0 \mathrm{ab}$ & 39.75 & $80.0 \mathrm{~d}$ & 14.28 \\
\hline Hydroquinone (HQ) & $6.60 \mathrm{abc}$ & 50.74 & $10.0 \mathrm{ab}$ & 39.75 & $83.40 \mathrm{~cd}$ & 19.14 \\
\hline T. harzianum + SA & $6.70 \mathrm{abc}$ & 50.00 & $3.30 \mathrm{bc}$ & 80.12 & $90.0 \mathrm{bc}$ & 28.57 \\
\hline T. harzianum + HQ & $3.40 \mathrm{bc}$ & 74.62 & $6.60 \mathrm{bc}$ & 60.24 & $90.0 \mathrm{bc}$ & 28.57 \\
\hline B. subtilis + SA & $6.70 \mathrm{abc}$ & 50.00 & $6.60 \mathrm{bc}$ & 60.24 & $86.70 \mathrm{bcd}$ & 23.85 \\
\hline B. subtilis + HQ & $6.70 \mathrm{abc}$ & 50.00 & $3.30 \mathrm{bc}$ & 80.12 & $90.0 \mathrm{bc}$ & 28.57 \\
\hline Topsin M-70® & $3.30 \mathrm{bc}$ & 75.37 & $3.30 \mathrm{bc}$ & 80.12 & $93.40 \mathrm{ab}$ & 33.42 \\
\hline Infested control & $13.40 \mathrm{a}$ & - & $16.60 \mathrm{a}$ & - & $70.0 \mathrm{e}$ & - \\
\hline Healthy control & $0.00 \mathrm{c}$ & - & $0.00 \mathrm{c}$ & - & $100.0 \mathrm{a}$ & - \\
\hline
\end{tabular}

(B) Fusarium oxysporum f. sp. lupini

\begin{tabular}{|c|c|c|c|c|c|c|}
\hline \multirow{3}{*}{ Treatments } & \multicolumn{4}{|c|}{ Wilted plants $\%$} & \multirow{3}{*}{$\begin{array}{l}\text { Survived } \\
\text { Plants \% }\end{array}$} & \multirow{3}{*}{$\begin{array}{c}\text { Increasing } \\
\%\end{array}$} \\
\hline & \multicolumn{2}{|c|}{ Early wilt } & \multicolumn{2}{|c|}{ Late wilt } & & \\
\hline & Incidence $\%$ & Reduction \% & Incidence \% & Reduction \% & & \\
\hline T. harzianum & $10.0 \mathrm{ab}$ & 39.75 & $10.0 \mathrm{~b}$ & 50.0 & $80.00 \mathrm{~d}$ & 26.18 \\
\hline B. subtilis & $10.0 \mathrm{ab}$ & 39.75 & $10.0 \mathrm{~b}$ & 50.0 & $80.00 \mathrm{~d}$ & 26.18 \\
\hline Salicylic acid (SA) & $10.0 \mathrm{ab}$ & 39.75 & $10.0 \mathrm{~b}$ & 50.0 & $80.00 \mathrm{~d}$ & 26.18 \\
\hline Hydroquinone (HQ) & $6.60 \mathrm{bc}$ & 60.24 & $10.0 \mathrm{~b}$ & 50.0 & $83.40 \mathrm{~cd}$ & 31.54 \\
\hline T. harzianum + SA & $6.70 \mathrm{bc}$ & 59.63 & $6.60 \mathrm{bc}$ & 67.0 & $86.70 \mathrm{bcd}$ & 36.75 \\
\hline T. harzianum + HQ & $6.70 \mathrm{bc}$ & 59.63 & $3.30 \mathrm{bc}$ & 83.50 & $90.0 \mathrm{bc}$ & 41.96 \\
\hline B. subtilis + SA & $3.30 \mathrm{bc}$ & 80.12 & $10.0 \mathrm{~b}$ & 50.0 & $86.70 \mathrm{bcd}$ & 36.75 \\
\hline B. subtilis $+\mathrm{HQ}$ & $6.70 \mathrm{bc}$ & 59.63 & $6.60 \mathrm{bc}$ & 67.0 & $86.70 \mathrm{bcd}$ & 36.75 \\
\hline Topsin M-70® & $3.30 \mathrm{bc}$ & 80.12 & $3.30 \mathrm{bc}$ & 83.50 & $93.40 \mathrm{ab}$ & 47.32 \\
\hline Infested control & $16.60 \mathrm{a}$ & - & $20.0 \mathrm{a}$ & - & $63.40 \mathrm{e}$ & - \\
\hline Healthy control & $0.00 \mathrm{c}$ & - & $0.00 \mathrm{c}$ & - & $100.0 \mathrm{a}$ & - \\
\hline
\end{tabular}

Different letters indicate significant differences among treatments within the same column according to least significant difference test $(p \leq 0.05)$.

Egypt. J. Phytopathol., Vol. 47, No. 1 (2019) 


\section{3- Field experiments:}

3.1 - Effect of biocontrol agents and chemical inducers on the incidence of lupine root- rot and Fusarium wilt diseases under field conditions

The efficacy of chemical inducers and biocontrol agents individually and/or in combination as seed soaking against the incidence of damping-off and root rot/wilt diseases of lupine plants, was evaluated under field conditions at Ismailia and Sers El-layian, Agric. Res. Stations during winter season 2017/2018. Data in Table (4) show that all treatments significantly reduced damping-off and root-rot/wilt incidence with variable degrees compared to the check. Soaking lupine seeds in a mixture of biocontrol agents and chemical inducers was more effective than using either alone. Also, the obtained data show that soaking seeds in any biocontrol agent (T. harzianum and B. subtilis) was more effective to reduce damping-off and root rot/wilt incidence than any of the chemical inducers (SA or HQ). At Ismailia Agricultural Research Station, Topsin M-70® recorded the highest increasing over control followed by $T$. harzianum $+\mathrm{HQ}, T$. harzianum $+\mathrm{SA}$ and B. subtilis $+\mathrm{HQ}$, respectively. In the contrary, lupine seeds soaked in SA treatment individually recorded the lowest one. While at Sers El-layian Agric. Res. Station, Topsin M-70® recorded the highest increasing over control followed by $T$. harzianum $+\mathrm{SA}, T$. harzianum + HQ and B. subtilis + HQ treatments, respectively.

3.2- Effect of biocontrol agents and chemical inducers on growth parameters and yield components of lupine plants under field conditions

Data in Table (5) indicate that the plant height was affected by seed treatments with the combination of chemical inducers and biocontrol agents in the two locations and all treatments significantly increased plant height as compared to untreated control. The maximum plant height was recorded due to using $T$. harzianum + HQ and T. harzianum + SA treatments at Ismailia and Sers El-layian Agric. Res. Stations, respectively. In addition, all treatments in the two locations showed significantly an increase in number of branches as compared to untreated control. The highest significant increase in the number of branches per plant was recorded due to using $T$. harzianum $+\mathrm{HQ}$ followed by $T$. harzianum $+\mathrm{SA}$ at Ismailia Agricultural Research Station. While, at Sers El-layian Agricultural Research Station, T. harzianum + SA was the most effective in this respect. Also, all treatments significantly increased number of pods per plant and seed weight per plant as compared to untreated control. The maximum number of pods per plant and seed weight per plant was recorded due to using T. harzianum + HQ treatment in the two locations. All treatments significantly increased the weight of one hundred seed as compared with untreated control. The seed treatments with T. harzianum + HQ and $T$. harzianum + SA significantly increased the weight of one hundred seed at Ismailia and Sers El-layian Agricultural Research Stations, respectively. Data collected from the two locations showed nearly similar results which indicated that 
all treatments significantly increased the seed yield as compared to untreated control. At Ismailia the maximum seed yield was recorded due to using $T$. harzianum + HQ treatment followed by T. harzianum + SA treatment. At Sers Ellayian, the maximum seed yield was recorded due to using T. harzianum + SA. On the contrary, a lupine seed soaked in Topsin M-70® treatment was less effective in both seasons compared the other treatments. In general, the combination between biocontrol agents and chemical inducers significantly improved lupine plants growth more than using each individually. Also, seeds soaked in any of biocontrol agents were more effective in this respect than using any chemical inducer.

Table (4): Effect of some biocontrol agents and chemical inducers on root- rot and Fusarium wilt disease incidence of lupine plants grown under field conditions at Ismailia and Sers El-layian Agricultural Research Stations during winter growing season 2017/2018.

\begin{tabular}{|c|c|c|c|c|c|c|c|c|}
\hline \multirow[b]{2}{*}{ Treatments } & \multicolumn{2}{|c|}{ Damping- off $\%$} & \multicolumn{2}{|c|}{ Root rot $\%$} & \multicolumn{2}{|c|}{ Wilted plants $\%$} & \multirow[b]{2}{*}{$\begin{array}{l}\text { Survived } \\
\text { plants \% }\end{array}$} & \multirow[b]{2}{*}{$\begin{array}{c}\text { Increasing } \\
\%\end{array}$} \\
\hline & $\begin{array}{c}\text { Incidence } \\
\%\end{array}$ & $\begin{array}{c}\text { Reduction } \\
\%\end{array}$ & $\begin{array}{c}\text { Incidence } \\
\%\end{array}$ & $\begin{array}{c}\text { Reduction } \\
\%\end{array}$ & $\begin{array}{c}\text { Incidence } \\
\%\end{array}$ & $\begin{array}{c}\text { Reduction } \\
\%\end{array}$ & & \\
\hline \multicolumn{9}{|c|}{ Ismailia Agricultural Research Station } \\
\hline T. harzianum & $6.00 \mathrm{~cd}$ & 60.42 & $2.70 \mathrm{~b}$ & 44.55 & $3.14 \mathrm{ab}$ & 43.62 & $88.24 \mathrm{e}$ & 18.44 \\
\hline B. subtilis & $8.00 \mathrm{bcd}$ & 47.22 & $1.60 \mathrm{bc}$ & 67.14 & $2.00 \mathrm{~b}$ & 64.10 & $88.46 \mathrm{e}$ & 18.74 \\
\hline Salicylic acid (SA) & $10.27 \mathrm{~b}$ & 32.25 & $2.27 \mathrm{bc}$ & 53.38 & $0.24 \mathrm{~b}$ & 95.70 & $85.13 \mathrm{~g}$ & 14.27 \\
\hline Hydroquinone (HQ) & $9.80 \mathrm{bc}$ & 35.35 & $1.57 \mathrm{bc}$ & 67.76 & $2.24 \mathrm{~b}$ & 59.78 & $86.50 \mathrm{f}$ & 16.10 \\
\hline T. harzianum + SA & $6.24 \mathrm{bcd}$ & 58.84 & $0.90 \mathrm{c}$ & 81.52 & $1.80 \mathrm{~b}$ & 67.68 & $91.14 \mathrm{c}$ & 22.33 \\
\hline T. harzianum + HQ & $5.14 \mathrm{~d}$ & 66.10 & $1.14 \mathrm{bc}$ & 76.60 & $1.80 \mathrm{~b}$ & 67.68 & $92.00 \mathrm{~b}$ & 23.48 \\
\hline B. subtilis + SA & $8.46 \mathrm{bcd}$ & 44.20 & $1.36 \mathrm{bc}$ & 72.07 & $1.56 \mathrm{~b}$ & 72.00 & $88.70 \mathrm{e}$ & 19.06 \\
\hline B. subtilis + HQ & $6.94 \mathrm{bcd}$ & 54.22 & $1.37 \mathrm{bc}$ & 71.87 & $1.80 \mathrm{~b}$ & 67.68 & $90.00 \mathrm{~d}$ & 20.80 \\
\hline Topsin M-70® & $5.60 \mathrm{~cd}$ & 63.00 & $0.70 \mathrm{c}$ & 85.62 & $0.70 \mathrm{~b}$ & 87.43 & $93.13 \mathrm{a}$ & 25.00 \\
\hline Control & $15.16 \mathrm{a}$ & - & $4.87 \mathrm{a}$ & - & $5.57 \mathrm{a}$ & - & $74.50 \mathrm{~h}$ & - \\
\hline \multicolumn{9}{|c|}{ Sers El-layian Agricultural Research Station } \\
\hline T. harzianum & $8.60 \mathrm{c}$ & 43.80 & $0.90 \mathrm{~b}$ & 77.50 & $0.90 \mathrm{bc}$ & 59.00 & $89.60 \mathrm{~d}$ & 14.14 \\
\hline B. subtilis & $7.80 \mathrm{~cd}$ & 49.00 & $1.10 \mathrm{~b}$ & 72.50 & $1.30 \mathrm{abc}$ & 40.90 & $89.80 \mathrm{~d}$ & 14.40 \\
\hline Salicylic acid (SA) & $11.00 \mathrm{~b}$ & 28.10 & $1.80 \mathrm{~b}$ & 55.00 & $1.60 \mathrm{ab}$ & 27.27 & $85.60 \mathrm{e}$ & 9.00 \\
\hline Hydroquinone (HQ) & $10.70 \mathrm{~b}$ & 30.00 & $1.30 \mathrm{~b}$ & 67.50 & $0.80 \mathrm{bc}$ & 63.63 & $87.20 \mathrm{e}$ & 11.00 \\
\hline T. harzianum + SA & $5.60 \mathrm{ef}$ & 63.40 & $1.10 \mathrm{~b}$ & 72.50 & $0.70 \mathrm{bc}$ & 68.20 & $92.60 \mathrm{ab}$ & 17.96 \\
\hline T. harzianum + HQ & $6.40 \mathrm{def}$ & 58.16 & $0.90 \mathrm{~b}$ & 77.50 & $0.90 \mathrm{bc}$ & 59.00 & $91.80 \mathrm{abc}$ & 16.94 \\
\hline B. subtilis + SA & 7.10 cde & 53.60 & $1.30 \mathrm{~b}$ & 67.50 & $1.10 \mathrm{bc}$ & 50.00 & $90.50 \mathrm{~cd}$ & 15.30 \\
\hline B. subtilis + HQ & 7.10 cde & 53.60 & $0.90 \mathrm{~b}$ & 77.50 & $0.90 \mathrm{bc}$ & 59.00 & $91.10 \mathrm{bcd}$ & 16.00 \\
\hline Topsin M-70® & $5.20 \mathrm{f}$ & 66.00 & $0.90 \mathrm{~b}$ & 77.50 & $0.40 \mathrm{c}$ & 81.81 & $93.50 \mathrm{a}$ & 19.10 \\
\hline Control & $15.30 \mathrm{a}$ & - & $4.00 \mathrm{a}$ & - & $2.20 \mathrm{a}$ & - & $78.50 \mathrm{f}$ & - \\
\hline
\end{tabular}

Different letters indicate significant differences among treatments within the same column according to least significant difference test $(p \leq 0.05)$.

Egypt. J. Phytopathol., Vol. 47, No. 1 (2019) 
Table (5): Effect of some biocontrol agents and chemical inducers on some growth parameters of lupine plants grown under field conditions at Ismailia and Sers El-layian Agricultural Research Stations during winter growing season 2017-2018.

\begin{tabular}{|c|c|c|c|c|c|c|}
\hline Tre: & $\begin{array}{l}\text { Plant } \\
\text { height } \\
(\mathrm{cm})\end{array}$ & $\begin{array}{c}\text { Branches } \\
\text { Number/ } \\
\text { plant }\end{array}$ & $\begin{array}{c}\text { Pods } \\
\text { number } \\
\text { /plant }\end{array}$ & $\begin{array}{l}\text { Seed yield } \\
\text { /plant } \\
\text { (g) }\end{array}$ & $\begin{array}{l}100 \text { seed } \\
\text { Weight } \\
(\mathrm{g})\end{array}$ & $\begin{array}{c}\text { Seed yield } \\
\text { weight } \\
(\mathrm{Kg} / \\
\text { feddan })\end{array}$ \\
\hline \multicolumn{7}{|c|}{ Ismailia Agricultural Research Station } \\
\hline T. harzianum & $122.60 \mathrm{a}$ & $19.00 \mathrm{ab}$ & $26.50 \mathrm{abc}$ & $31.70 \mathrm{a}$ & $33.20 \mathrm{abc}$ & $1336.16 \mathrm{e}$ \\
\hline B. subtilis & $120.60 \mathrm{a}$ & $18.80 \mathrm{ab}$ & $25.40 \mathrm{abc}$ & $28.50 \mathrm{ab}$ & 30.70 & $1300.00 \mathrm{f}$ \\
\hline Salicylic acid (SA) & $92.20 \mathrm{c}$ & $13.60 \mathrm{bc}$ & $21.20 \mathrm{c}$ & $27.96 \mathrm{ab}$ & 27.60 cde & $1250.80 \mathrm{~g}$ \\
\hline Hydroquinone (HQ) & $106.20 \mathrm{~b}$ & $14.40 \mathrm{bc}$ & $22.00 \mathrm{bc}$ & $28.00 \mathrm{ab}$ & 28.0 bcde & $1291.80 \mathrm{f}$ \\
\hline T. harzianum $+\mathrm{SA}$ & $126.20 \mathrm{a}$ & $24.20 \mathrm{a}$ & $33.50 \mathrm{a}$ & $36.90 \mathrm{a}$ & $34.40 \mathrm{ab}$ & $1609.00 \mathrm{~b}$ \\
\hline T. harzianum + HQ & $127.00 \mathrm{a}$ & 24 & $33.70 \mathrm{a}$ & $37.30 \mathrm{a}$ & 37.7 & $1680.16 \mathrm{a}$ \\
\hline B. subtilis $+\mathrm{SA}$ & $\mathrm{a}$ & a & $30.80 \mathrm{ab}$ & $32.60 \mathrm{a}$ & 34.0 & $1410.50 \mathrm{~d}$ \\
\hline B. subtilis + HQ & a & a & $\mathrm{a}$ & 34.7 & 34.3 & $1516.00 \mathrm{c}$ \\
\hline Topsin $\mathrm{N}$ & 8 & 13 & 17. & 18.3 & 25.3 & $900.80 \mathrm{~h}$ \\
\hline Control & $79.40 \mathrm{~d}$ & $10.40 \mathrm{c}$ & $12.00 \mathrm{~d}$ & $15.80 \mathrm{c}$ & 23 & $838.70 \mathrm{i}$ \\
\hline \multicolumn{7}{|c|}{ Sers El-layian Agricultural Research Station } \\
\hline T. harzianum & $125.00 \mathrm{bc}$ & $4.00 \mathrm{abc}$ & $26.33 \mathrm{~cd}$ & 31.67 cde & $34.33 \mathrm{abc}$ & $1440.0 \mathrm{de}$ \\
\hline B. subtilis & $123.33 \mathrm{bc}$ & $4.00 \mathrm{abc}$ & $25.00 \mathrm{~d}$ & $31.00 \mathrm{de}$ & $34.33 \mathrm{abc}$ & $1365.0 \mathrm{ef}$ \\
\hline Salicylic acid (SA) & $103.33 \mathrm{e}$ & $5.67 \mathrm{a}$ & $32.33 \mathrm{abc}$ & $28.00 \mathrm{e}$ & $29.00 \mathrm{~cd}$ & $1320.0 \mathrm{f}$ \\
\hline Hydroquinone (HQ) & $118.33 \mathrm{bc}$ & $3.67 \mathrm{bc}$ & $27.67 \mathrm{bcd}$ & $27.67 \mathrm{e}$ & $31.00 \mathrm{bcd}$ & $1330.0 \mathrm{f}$ \\
\hline T. harzianum + SA & $141.67 \mathrm{a}$ & $5.67 \mathrm{a}$ & $33.33 \mathrm{ab}$ & $36.67 \mathrm{ab}$ & $40.00 \mathrm{a}$ & $1850.0 \mathrm{a}$ \\
\hline T. harzianum + HQ & $125.00 \mathrm{bc}$ & $5.33 \mathrm{ab}$ & $35.00 \mathrm{a}$ & $38.67 \mathrm{a}$ & $36.66 \mathrm{ab}$ & $1750.0 \mathrm{~b}$ \\
\hline B. subtilis + SA & $128.33 \mathrm{~b}$ & $5.00 \mathrm{ab}$ & $24.00 \mathrm{de}$ & $34.33 \mathrm{bcd}$ & $34.67 \mathrm{abc}$ & $1500.0 \mathrm{~d}$ \\
\hline B. subtilis $+\mathrm{HQ}$ & $111.67 \mathrm{~d}$ & $4.33 \mathrm{abc}$ & $23.33 \mathrm{de}$ & $35.67 \mathrm{abc}$ & $33.67 \mathrm{bc}$ & $1650.0 \mathrm{c}$ \\
\hline Topsin M-70® & $93.33 \mathrm{f}$ & $3.00 \mathrm{c}$ & $31.67 \mathrm{abc}$ & $27.67 \mathrm{e}$ & $27.33 \mathrm{~d}$ & $1290.0 \mathrm{f}$ \\
\hline Control & $76.67 \mathrm{~g}$ & $3.00 \mathrm{c}$ & $18.33 \mathrm{e}$ & $23.33 \mathrm{f}$ & $20.00 \mathrm{e}$ & $900.0 \mathrm{~g}$ \\
\hline
\end{tabular}

Different letters indicate significant differences among treatments within the same column according to least significant difference test $(p \leq 0.05)$.

3.3- Effect of lupine seed treatment with some biocontrol agents and chemical resistance inducers on activity of peroxidase and polyphenoloxidase enzymes and phenol contents:

A-Activity of oxidative enzymes

Activities of peroxidase (PO) and polyphenoloxidase (PPO) enzymes of lupine plants raised from seeds treated with some biocontrol agents and chemical inducers were evaluated. Data in Table (6) show that all treatments were effective in eliciting 
the enzyme activities (peroxidase and polyphenoloxidase). The maximum activities as compared to the untreated control of the two enzymes were recognized with $T$. harzianum + HQ treatment followed by $T$. harzianum + SA and B. subtilis + HQ treatments, respectively. In general, data indicate that the combination of biocontrol agents and chemical inducers was more effective in enhancing the enzyme activities of lupine plants more than using each individually. Also, soaking seeds in any of the chemical inducers was more effective in this respect than using any of biocontrol agents alone.

\section{$B$ - Total phenol content:}

Total phenols contents were highly enhanced in lupine plants raised from seeds treated with different biocontrol agents and chemical resistance inducers individually or in combination compared to untreated control. Data in Table (6) indicate that the highest increase in the total phenol contents was recorded due to using $T$. harzianum + HQ treatment followed by using B. subtilis + HQ treatments compared to untreated control. Whereas, the less increases were recognized in total phenols content, when T. harzianum and / or Topsin M-70® treatments were individually applied compared to untreated control. Also, Data indicate that the combination of biocontrol agents and chemical inducers was more effective in enhancing total phenols content of lupine plants more than using each individually.

Table (6): Effect of some biocontrol agents and chemical resistance inducers as seed treatments on activity of peroxidase, polyphenoloxidase and total phenol content in lupine plants

\begin{tabular}{lcccccc}
\hline & $\begin{array}{c}\text { Peroxidase activity } \\
\text { (absorbance at 430 nm) }\end{array}$ & $\begin{array}{c}\text { Polyphenoloxidase } \\
\text { activity } \\
\text { Treatments }\end{array}$ & Activity $\begin{array}{c}\text { Increasing } \\
\text { over } \\
\text { control \% }\end{array}$ & Activity & $\begin{array}{c}\text { Increasing } \\
\text { over } \\
\text { control \% }\end{array}$ & $\begin{array}{c}\text { Total phenols (mg/g } \\
\text { fresh leave weight) } \\
\text { (absorbance at 725 nm) }\end{array}$ \\
\hline T. harzianum & 0.266 & 82.19 & 0.063 & 133.40 & 47.00 & $\begin{array}{c}\text { Increasing } \\
\text { over } \\
\text { control \% }\end{array}$ \\
B. subtilis & 0.287 & 96.57 & 0.066 & 144.50 & 47.50 & 3.26 \\
Salicylic acid (SA) & 0.284 & 94.52 & 0.070 & 159.25 & 47.50 & 3.26 \\
Hydroquinone (HQ) & 0.293 & 100.68 & 0.073 & 170.37 & 48.00 & 4.34 \\
T. harzianum + SA & 0.311 & 113.00 & 0.081 & 200.00 & 49.50 & 7.60 \\
T. harzianum + HQ & 0.324 & 121.92 & 0.085 & 214.81 & 53.50 & 16.30 \\
B. subtilis + SA & 0.304 & 108.21 & 0.075 & 177.80 & 48.50 & 5.43 \\
B. subtilis + HQ & 0.308 & 110.96 & 0.078 & 188.90 & 50.00 & 8.70 \\
Topsin M-70® & 0.215 & 47.26 & 0.062 & 129.62 & 47.00 & 2.17 \\
Control & 0.146 & - & 0.027 & - & 46.00 & - \\
\hline
\end{tabular}

Egypt. J. Phytopathol., Vol. 47, No. 1 (2019) 
3.4- Effect of lupine seed treatment with some biocontrol agents and chemical resistance inducers on chlorophyll and carotenoids contents:

All treatments increased chlorophyll and carotenoids contents compared with control plants (Table 7). The highest chlorophyll a and carotenoids contents were found in plants raised from seeds treated with $T$. harzianum $+\mathrm{HQ}$, followed by Salicylic acid (SA). While, B. subtilis + HQ treatment was the most effective in stimulating chlorophyll b. In general, seed treatment with the combination of biocontrol agents and chemical resistance inducers appeared to stimulate chlorophyll synthesis or at least eliminate the adverse effect of the phytopathogens on pigment formation.

Table (7): Effect of lupine seed treatment with some biocontrol agents and chemical resistance inducers on chlorophyll and carotenoids contents.

\begin{tabular}{lccc}
\hline \multicolumn{1}{c}{ Treatments } & $\begin{array}{c}\text { Chlorophyll, A } \\
\text { content } \\
\text { (mg/g fresh } \\
\text { leaves weight) }\end{array}$ & $\begin{array}{c}\text { Chlorophyll, B } \\
\text { content } \\
\text { (mg/g fresh } \\
\text { leaves weight) }\end{array}$ & $\begin{array}{c}\text { Carotenoids } \\
\text { content } \\
\text { (mg/g fresh } \\
\text { leaves weight) }\end{array}$ \\
\hline T. harzianum & 0.678 & 0.107 & 0.462 \\
B. subtilis & 0.331 & 0.004 & 0.171 \\
Salicylic acid (SA) & 0.820 & 0.136 & 0.527 \\
Hydroquinone (HQ) & 0.749 & 0.130 & 0.472 \\
T. harzianum + SA & 0.631 & 0.119 & 0.385 \\
T. harzianum + HQ & 0.822 & 0.160 & 0.530 \\
B. subtilis + SA & 0.784 & 0.160 & 0.505 \\
B. subtilis +HQ & 0.461 & 0.179 & 0.327 \\
Topsin M-70® & 0.384 & 0.075 & 0.256 \\
Control & 0.249 & 0.032 & 0.152 \\
\hline
\end{tabular}

\section{D is c u s s i on}

White lupine (Lupinus albus .L) is one of the oldest agricultural crops widely used in the world not only as a protein source in fodder production but also for soil improvement. Lupine seeds contain considerable nutrition due to its high protein (35-45\%) and oil content (10-15\%). Many soil-borne fungi, including $R$. solani Kühn and $F$. oxysporum Shelct infect lupine plants causing damping-off, root rot and wilt diseases. Such diseases cause great decrease in seed yield (Abdel-Monaim, 2008; Ali et al., 2009). 
Plant pathologists make great efforts to minimize the use of synthetic fungicides and to optimize the use of alternative management strategies to control soil-borne pathogens. Acquired systemic resistance that increases plant resistance to subsequent pathogen attack, by using biotic (microorganisms) or abiotic (chemicals) agents as inducers seem to be one of alternatives to substitute for, or at least to decrease the use of fungicides in plant disease control. Resistance induced by these agents has broad spectrum against numerous pathogens and long lasting, but rarely provides complete control of infection, as many resistance elicitors provide between 20 and 85\% disease control (Walters et al., 2013).

Antagonistic fungi and bacteria in plant root zone are a key agent of change in soil agro-ecosystems. Interactions between plant root systems and rhizobacteria have a profound effect on crop health, yield and soil quality. Root zone antagonistic fungi and bacteria are able to generate a wide array of secondary metabolites which can have a positive influence on plant growth; enhancing the availability of mineral nutrients, improving nitrogen fixation ability, decreasing susceptibility to frost damage, improving plant health through the biocontrol of phytopathogens, inducing systemic plant disease resistance and facilitating plant establishment, growth and development (Sturz and Christie, 2003). Plants respond to chemical elicitor treatments by activating a wide variety of protective mechanisms designed to prevent pathogen replication and spreading (Malolepsza and Rozalaska, 2005). The defense mechanisms include the fast production of reactive oxygen species (De Gara et al., 2003); alterations in the cell wall constitution; accumulation of antimicrobial secondary metabolites known as phytoalexins (Agrios, 2005); activation and/or synthesis of defense peptides and proteins (Castro and Fontes, 2005).

This study was planned to investigate the possibility of minimizing the infection with damping-off, root rot and wilt diseases of lupine using biocontrol agents ( $T$. harzianum and B. subtilis) and chemical resistance inducers (SA and HQ) individually and/or in combinations. The obtained data in vitro revealed that both biocontrol agents and chemical inducers individually and/or in combination caused significant linear growth reduction of the two tested pathogenic fungi but with variable degrees. The combinations of biocontrol agents and chemical inducers inhibited the fungal growth than using each individually especially in case of $B$. subtilis + SA and B. subtilis + HQ.

In addition, all treatments caused significant reduction to infection by dampingoff and root rot/wilt diseases and increased the plant survival either in pots or in the field experiments, compared to the control treatments. The combinations of biocontrol agents and chemical resistance inducers were more effective to reduce damping-off, root rot/wilt severity and increased survived plants than using each individually. The combination between each of HQ and/or SA and T. harzianum recorded the best results in this respect. These results are in agreement with those reported by Abdel-Monaim (2010). Also, Saikia et al. (2003) studied the efficiency

Egypt. J. Phytopathol., Vol. 47, No. 1 (2019) 
of $P$. fluorescence with or without SA amendment in chickpea against Fusarium wilt infection, and found that application of $P$. fluorescence (pf4-92) with SA exhibited the highest protection of chickpea seedlings against wilting.

Regarding to seed soaking application with biocontrol agents and chemical inducers individually or in combination in both locations (Ismailia and Sers Ellayian Research Stations Farms during 2017/2018 growing season) showed a significant increase in lupine growth parameters and yield components. The combinations of biocontrol agents and chemical resistance inducers recorded high increase in all growth and yield parameters more than in using each individually. This increasing may be attributed to biotic and abiotic elicitors effect on physiological processes in plant such as ion uptake, cell elongation, cell division, enzymatic activation. In this concern, low SA and HQ doses enhanced growth and yield components of tomato (Abdel-Monaim et al., 2012) and Snap bean (Sarhan et al., 2018). Also, Trichoderma and Bacillus increased plant growth and yield components in many plant species (Abdel-Monaim, 2010 and El-Shabrawy and Shehata, 2018). Also, these results show that the biocontrol efficiency of antagonists T. harzianum and B. subtilis may be stimulated by SA and HQ resulting in a significant increase in their population density and antagonistic effect against the tested pathogens.

Some Trichoderma biological control agents (BCAs) produce highly efficient siderophores that chelate iron and stop the growth of other fungi (Chet and Inbar, 1994). Substantial information provides support that the extraordinary capacity of $T$. harzianum to attack the structures of phytopathogenic fungi and sclerotial degradation by mycoparasitism which has been observed for $R$. solani (Almeida $e t$ al., 2007). Meanwhile, T. harzianum is well known producer of antibiotic (produced by some but not all strains) that are toxic for phytopathogenic fungi, including 6pentyl-a-pyrone (Scarselletti and Faull 1994); Harzianopyridone, Harzianic acid and Harzianolide (Vinale et al., 2009) and Trichorzianines-A (El-Hajji et al., 1987). Strains of Trichoderma are always associated with plant roots and root ecosystems. However, some authors have defined Trichoderma strains as plant symbiont opportunistic avirulent organisms, able to colonize plant roots by mechanisms similar to those of mycorrhizal fungi and to produce compounds that stimulate growth and plant defense mechanisms.

Many Bacillus species have been used either alone or in combination to control fungal pathogens (Falconi et al., 2004). This can be attributed to a variety of mechanisms: the induction of systemic resistance, the promotion of host growth (Kloepper et al., 2004) and/or antibiosis.

However, the present results indicated that combined seed treatments with $T$. harzianum + HQ followed by $T$. harzianum $+\mathrm{SA}$ and $B$. subtilis $+\mathrm{HQ}$, respectively were effective in eliciting the enzyme activities (peroxidase PO and polyphenol 
oxidase PPO) than using any of them individually. The increase of activity was associated with increasing resistance against infection by many diseases (Wang et al., 2000; El-Shabrawy and Shehata, 2018 and Sarhan et al., 2018). The oxidation of phenols is mediated by the enzymes PO and PPO and the resulting quinones are effective inhibitors of $\mathrm{SH}$ group of enzymes which may be inhibiting to the pathogen (Goodman et al., 1967). Peroxidase is reported to have an important function in secondary cell wall biosynthesis by polymerizing hydroxy and methoxycinnamic alcohols into lignin and forming rigid cross-links between cellulose, pectin, hydroxyproline-rich glycoproteins (HRGP) and lignin (Grisebach, 1981). Therefore, Peroxidase may be directly associated with the increased ability of systemically protected tissue to lignify which may restrict the penetration (Gross, 1979). Meantime, polyphenoloxidase (PPO) is a widespread enzyme found in plant cells, located in the chloroplast thylakoid membranes and plays an important role in plant resistance. However, it indicates the highest activity toward hydroxylation of monophenols to diphenols, and is capable of dehydrogenating of o-diphenols to produce o-quinones (antimicrobial compounds) as well as lignifications of plant cells during microbial invasion (Meyer, 1987). Polyphenoloxidases are suggested to be indirectly involved in auxin biosynthesis because the o-quinones produced then can react with tryptophan to form indole-3-acetic acid (Mayer and Harel, 1979). Furthermore, the treatments led to increase the total phenolic content compared with the untreated control. In this respect, the role of phenolic compounds in disease resistance was postulated by many authors (Nicholson and Hammerschmidt, 1992). They indicated that phenols are oxidized to quinones or semi-quinones which are more toxic and play a great role as antimicrobial substances on the invaded pathogen (Farkas and Kiraly, 1962).

On the other hand, results exhibited that infection of lupine plants with either $F$. oxysporum or $R$. solani decreased both chlorophyll a, b and carotenoids contents. Chlorosis of plant tissue is a common visible symptoms following infection with phytopathogenic fungi. It may result as a consequence of either a) photo oxidative destruction of existing pigments, or b) inhibition of pigment synthesis. It is possible that the effect of phytopathogenic fungi on chlorophyll and carotenoids is an attenuation of the biosynthetic rate rather than a breakdown of pigments already formed. Kern (1972) reported that the adverse effect of fungal pathogen on chlorophyll pigments may be due to the fact that the fungal toxins form iron-chelate, transforming iron to become unavailable to participate in chlorophyll synthesis. Combined biocontrol agents with inducers appeared to stimulate chlorophyll synthesis or at least eliminate the adverse effect of the phytopathogens on pigment formation. Similar results were reported by Abdel-Monaim (2008) who found that lupine seed soaking in antioxidant solutions increased chlorophyll and carotenoids content in leaves and this reflects the health condition of the plant.

Egypt. J. Phytopathol., Vol. 47, No. 1 (2019) 
Results obtained indicated that soil biota determine, to a great extent the ability of biocontrol agents to alleviate the activity of pathogens. Thus, they might be considered a carrier stone in biocontrol agents -interaction.

The biocontrol agents acted more effectively against $R$. solani and $F$. oxysporum f.sp. lupini in clay soil (Sers El-layian Res. Station Farm) than in sandy soil (Ismailia Res. Station Farm). A synergistic relationship between biocontrol agents and natural soil microflora might exist.

\section{Conclusions}

From the aforementioned results, it can be concluded that treatments with biocontrol agents and chemical inducers in combination as seed treatments significantly increased plant resistance than using each individually against the infection by $R$. solani, or $F$. oxysporum f.sp. lupini, improved plant growth, yield, accumulation of some antimicrobial substances such as total phenols contents, stimulate chlorophyll synthesis and increasing activity of defence related enzymes. Such these treatments can be suggested as a part of integrated disease management for field crops.

\section{Ref e r e n c es}

Abdel-Monaim, M.F. 2008. Pathological Studies of Foliar and Root Diseases of Lupine with Special Reference to Induced Resistance. Ph.D. Thesis, Fac. Agric., Minia University. Pp.175.

Abdel-Monaim, M.F. 2010. Integrated management of damping-off, root and/or stem rot diseases of chickpea with sowing date, host resistance and bioagents. Egypt J. Phytopathol., 38: 45-61.

Abdel-Monaim, M.F.; Abdel-Gaid, M.A. and Armanious, H.A. 2012. Effect of chemical inducers on root rot and wilt diseases, yield and quality of tomato. Int. J. Agric. Sci., 7:211-20.

Agrios, G.N. 2005. Plant Pathology. $5^{\text {th }}$ ed. San Diego: Academic Press. Pp.952.

Ahmed, A.A. 2000. Studies on Some Factors Affecting Mycotoxin Stability in Wheat Grain and Its Products. M.Sc. Thesis, Fac. Scince, Ain-Shams Univ. 2426.

Ali, A.A.; Ghoneem, K.M.; El-Metwally, M.A. and El-Hai, K.M.A. 2009. Induce systemic resistance in lupine against root-rot diseases. Pak. J. Biol. Sci. 12(3): 213-221.

Almeida, F.B. dos R.; Cerqueira, F.M.; Silva, R. do N.; Ulhoa, C.J. and Lima, A.L. 2007. Mycoparasitism studies of Trichoderma harzianum strains against Rhizoctonia solani: evaluation of coiling and hydrolytic enzyme production. Biotech. Let., 29:1189-1193. 
Arnon, I. 1949. Copper enzymes in isolated chloroplast polyphenoloxidase in Beta vulgaris. Plant Physiol., 24:1-15.

Asaka, O. and Shoda, M. 1996. Biocontrol of Rhizoctonia solani damping-off of tomato with Bacillus subtilis RB14. Appl. Environ. Microbiol. 62, 4081-4085.

Bacon, C.W. and White, L.F. 2000. Microbial endophytes. Marcel Dekker Inc., New York, N.Y. Pp.500.

Castro, M.S. and Fontes, W. 2005.Plant defense and antimicrobial peptides. Protein Peptide Lett., 12: 11-6.

Chakraborty, M.R. and Chatterjee, N.C. 2007. Interaction of Trichoderma harzianum with Fusarium solani during its pathogenesis and the associated resistance of the host. Asian J. Exp. Sci., 21: 351-355.

Chet, I. and Inbar, J. 1994. Biological control of fungal pathogens. Appl. Biochem. Biotechnol., 48:37-43.

De Boer, W.; Gerards, S.; Klein Gunnewiek, P.J. and Modderman, R. 1999. Response of the chitinolytic microbial community to chitin amendments of dune soils. Biol. Fertil. Soils. 29:170-7.

De Gara, L.; De Pinto, M.C. and Tommasi, F. 2003. The antioxidant systems vis-àvis reactive oxygen species during plant-pathogen interaction. Plant Physiol. Biochem., 41: 863-70.

El-Hajji, M.; Rebuffat, S.; Lecommandeur, D. and Bodo, B. 1987. Isolation and sequence determination of trichorzianines A antifungal peptides from Trichoderma harzianum. Inte. J. Pept. Protein Res., 29: 207-215.

El-Shabrawy, E.M. and Shehata, H.S. 2018. Controlling maize late-wilt and enhancing plant salinity tolerance by some Rhizobacterial strains. Egypt J. Phytopathol., 46(1): 235-255.

El-Wakil, M.A. 2003. Use of antioxidant hydroquinone in the control of seed-borne fungi of peanut with special reference to the production of good quality seed. Pak. J. Plant Pathol., 2(2): 75-79.

Falconi, C.E.; Oleas, A.R. and Yanez, V.R. 2004. Biological control of monilia pod rot (Moniliophthora roreri) on "high flavor" cocoa's field using biopesticides based on Bacillus subtilis and Pseudomonas cepacia. Phytopath., 94, S28 (abstract).

Farkas, G.L. and Kiraly, Z. 1962. Role of phenolic compounds in the physiology of plant diseases and disease resistance. Phytopath. Z., 44: 105-150.

Egypt. J. Phytopathol., Vol. 47, No. 1 (2019) 
Goodman, R.N.; Kiraly, Z. and Zaitlin, M. 1967. The Biochemistry and Physiology of Infectious Plant Diseases. Van Nostrand Co. Inc., Princeton, New Jersey, Pp 354.

Govindappa, M.; Lokesh, S.; Rai, V.R.; Nail, V.R.; and Raju, S.G. 2010. Induction of systemic resistance and management of safflower Macrophomina phaseolina root rot disease by biocontrol agents. Archi. Phytopathol. Plant Protec., 43(1-3): 26-40.

Grisebach, H. 1981. Lignin. In: The Biochemistry of Plants, Vol. 7, Ed. by E.E. Conn, Academic Press, New York, pp. 451-478.

Gross, G.G. 1979. Recent advances in chemistry and biochemistry of lignin. Rec. Adv. Phytochem., 12: 177-220.

Jayalakshmi, S.K.; Raju, S.; Usha-Rani, S.; Benagi, V.I. and Sreeramulu, K. 2009. Trichoderma harzianum $\mathrm{L} 1$ as a potential source for lytic enzymes and elicitor of defense responses in chickpea (Cicer arietinum L.) against wilt disease caused by Fusarium oxysporum f. sp. ciceri. Aust. J. Crop Sci, 3(1): 44-52.

Julier, B.; Huyghe, C. and Papineau, J. 1994. Dry matter and nitrogen accumulation in indeterminate autumn-sown white lupine (Lupinus albus ) c.v. Lunoble. Eur. J. Agron., 3: 153-160 .

Kern, H. 1972. Phytotoxins produced by Fusaria. In: "Phytotoxins in plant diseases (Wood RKS, Ballio A, Graniti A. eds)". pp. 35-48, Acad. Press, London and New York.

Kloeppor, J.W.; Ryu, C.M. and Zhang, S. 2004. Induced systemic resistance and promotion of plant growth by Bacilus spp. Phytopath., 94: 1259-1266.

Malolepsza, U. and Rozalaska, S. 2005. Nitric oxide and hydrogen peroxide in tomato resistance: nitric oxide modulates hydrogen peroxide level in ohydroxyethylorutin-induced resistance to Botrytis cinerea in tomato. Plant Physiol. Biochem., 43:623-35.

Mayer, A.M. and Harel, E. 1979. Polyphenoloxidases in plants. Phytochem., 18: 193-215.

Meyer, A.M. 1987. Polyphenoloxidases in plants-recent progress. Phytochem., 26: 11-20.

Miller, G.L. 1959. Use of dinitrosalicylic acid reagent for determination of reducing sugar. Anal. Chem., 31(3): 426-428.

Monreal, J. and Reese, E.T. 1969. The Chitinase of Serratia marcescens. Canadian J. Microbiol., 15: 689-696. 
Nafie, E., and Mazen, M.M. 2008. Chemical induced resistance against brown stem rot in soybean: The effect of benzothiadiazole. J. App. Sci. Res., 4(12): 20462064.

Nicholson, R.L. and Hammerschmidt, R. 1992. Phenolic compounds and their role in disease resistance. Annual Rev. Phytopathol., 30: 369-389.

Okoth, S.A.; Otadoh, J.A. and Ochanda, J.O. 2011. Improved seedling emergence and growth of maize and beans by Trichoderma harzianum. Trop. Subtrop. Agroecosyst. 13: 65-71.

Papavizas, G.C. and Davey, C.B. 1962. Isolation and pathogenicity of Rhizoctonia saprophytically existing in soil. Phytopath., 52:834-840.

Roby, D.; Gadelle, A. and Toppan, A. 1987. Chitin oligosaccharides as elicitors of chitinase activity in melon plants. Biochem. Biophys. Res. Commun., 143: 88592.

Sadasivam, S. and Manickam, A. 1996. Biochemical Methods.Second Ed. New Age Int. Pvt. Ltd. Pub. and T.N. Agril. Univ. Coimbatore, Tamil Nadu, India, pp. 108-110.

Saikia, R.; Singh, T.; Kumar, R.; Srivastava, J.; Srivastava, A.K.; Singh, K. and Arora, D.K. 2003. Role of salicylic acid in systemic resistance induced by Pseudomonas fluorescens against Fusarium oxysprum f.sp. ciceri in chickpea. Microbiol. Res., 158: 203-213.

Sarhan, E.A.D. 2018. Induction of induced systemic resistance in fodder beet (Beta vulgaris L.) to Cercospora leaf spot caused by (Cercospora beticola Sacc.). Egypt J. Phytopathol., 46(2): 39-59.

Sarhan E.A.D.; El-Far, E.M.M. and Ebrahiem, A.M.Y. 2018. Systemic resistance in snap bean (Phaseolus vulgaris L.) elicited by some chemicals and biotic inducers against white mold disease caused by (Sclerotinia sclerotiorum). Egypt J. Phytopathol., 46(2): 61-84.

Sarwar, N.; Zahid, M.H.C. and Haq, I. 2010. Seed treatments induced systemic resistance in chickpea against Fusarium wilt in wilt sick field. Pak. J. Botany, 42(5): 3323-3326.

Sawai, K.O.; Okuno, T.; Terada, Y.; Harada, Y.; Saw, Amura, K.; Sasaki, H. and Takao, S. 1981. Isolation and properties of two antifungal substances from Fusarium solani. Agric. Biol. Chem., 45(5): 1223-1228.

Scarselletti, R. and Faull, J.L. 1994. In Vitro activity of 6-pentyl-a-pyrone, a metabolite of Trichoderma harzianum, in the inhibition of Rhizoctonia solani and Fusarium oxysporum f. sp. lycopersici. Mycol. Res., 98:1207-1209.

Egypt. J. Phytopathol., Vol. 47, No. 1 (2019) 
Silva, F.deA.S.e. and de Azevedo, C.A.V. 2009. Principal Components Analysis in the Software Assistat-Statistical Attendance. In: World Congress on Computers In Agriculture, 7, Reno-NV-USA: Amer. Soci. Agri. Bio. Engin.

Somogyi, M. 1945. A new reagent for the determination of sugars. J. Biol. Chem., 160: 61-68.

Sturz, A.V. and Christie, B.R. 2003. Beneficial microbial allelopathies in the root zone: the management of soil quality and plant disease with rhizobacteria. Soil Tillage Res., 72:107-23.

Tarber, R.; Kuhn, M.; Ruegger, A.; Lichti, H.; Loosli, H.R. and Wartburg, A. 1977. The structure of cyclosporine. C. Helv. Chim. Acta., 60(4): 1247- 1255.

Vinale, F.; Flematti, G.; Sivasithamparam, K.; Lorito, M.; Marra, R.; Skelton, B.W. and Ghisalberti, E.L. 2009. Harzianic acid, an antifungal and plant growth promoting metabolite from Trichoderma harzianum. J. Nat. Prod., 72: 20322035.

Walters, D.R.; Ratsep, J. and Havis, N.D. 2013. Controlling crop diseases using induced resistance: challenges for the future. J. Exp. Bot., 64: 1263-1280.

Wang, F.; Gao, R.J.; Li, J.O.; Wu, X.H. and Geny, P.T. 2000. Effect of difenoconazole on the growth and activities of disease resistance related enzymes in wheat seedlings from treated seeds. Acta Phytopathol. Sin., 30: 213-216.

Zian, A.H. 2011. Studies on Fusarium Wilt Disease of White Lupine Plants in Egypt. Ph.D. Thesis, Fac. Agric., Suez Canal Univ., Egypt. Pp.167.

Zieslin, N. and Ben-Zaken, R. 1993. Peroxidase activity and presence of phenolic substances in peduncles of rose flowers. Plant Physiol. Biochem., 31: 333- 339.

Corresponding author: Zian, A.H.

E-mail: ahmed_hanafy1001@yahoo.com

(Received 20/02/2019;

in revised form 15/03/2019) 


\section{تحسين عوامل المكافحة الحيوية بواسطة الهيدروكينون وحامض الساليسيليك لمكافحة أمراض عفن الجذئه بذور والأبول في الترمس فمن التمن \\ أحمد حنفي محمود زيان' ، هالة محمد رشاد الجندي' ،و هبه شحاتة

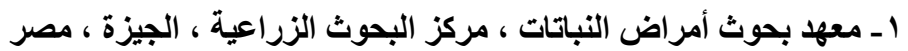

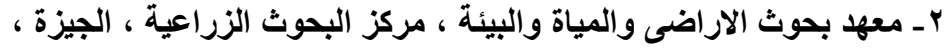

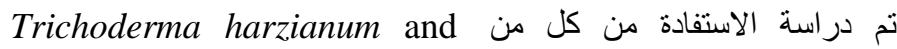

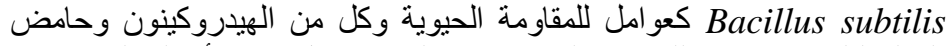

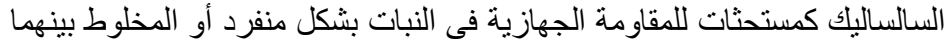

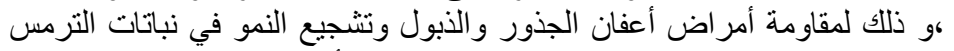

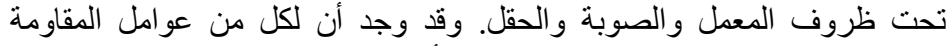

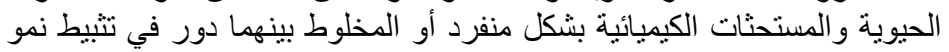

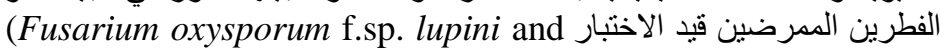
بدرجات مختلفة مقارنة بالكنترول ـ وقد اظهرت معاملة Rhizoctonia solani) B. subtilis

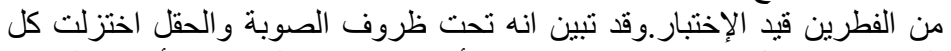

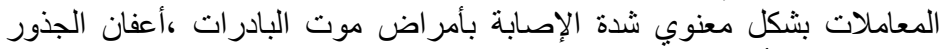

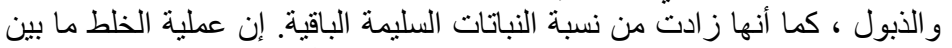

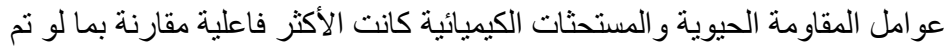

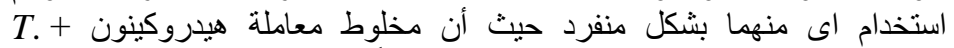

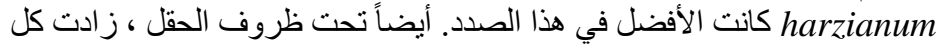

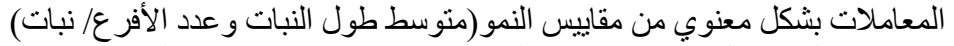

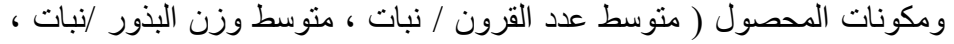

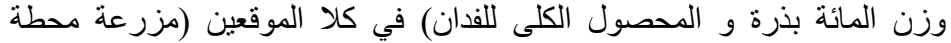

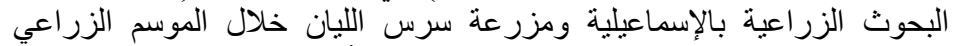

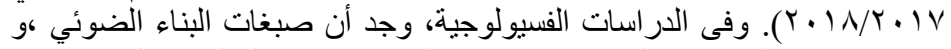

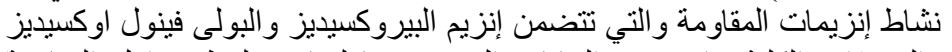

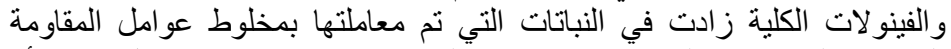

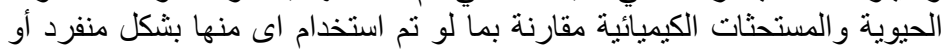

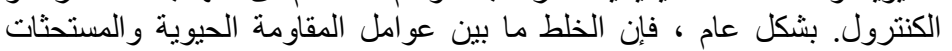

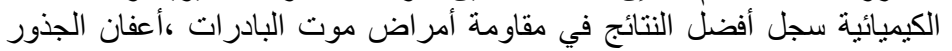

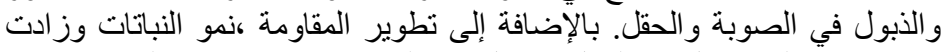

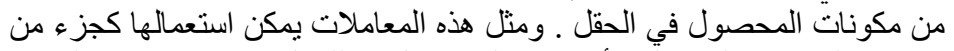

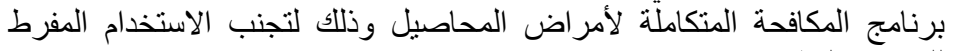

للمبيدات الفطرية. 